\title{
Asymmetric Federalism in India
}

\author{
M. Govinda Rao and Nirvikar Singh
}

Revised April 2004

\begin{abstract}
The focus of this paper is unequal arrangements and special treatment for some units within Indian federalism, namely. We first explore the conceptual issues - the causes and consequences of asymmetric federalism. Next, we trace the evolution of Indian federalism and analyze the factors contributing to the asymmetric arrangements in political, administrative and fiscal relations. We bring out asymmetric arrangements arising from constitutional arrangements or conventions evolved over the years. Recent political developments and asymmetric treatment due to administrative and political exigencies are also analyzed.
\end{abstract}

Keywords: intergovernmental transfers, federalism, political bargaining, constitutional arrangements

JEL codes: P26, P35, H1, H7 


\title{
Asymmetric Federalism in India
}

\author{
M. Govinda Rao and Nirvikar Singh*
}

\section{Introduction}

There can be a variety of motivations for various units to come together to constitute a federation. The political and economic theories of federalism attempt to understand the rationale for the "coming together" to form federations and once they are formed, analyse the conditions for "holding together". The political impulse for the smaller units to federate has to be found in issues of freedom, security, political stability and strength while keeping a separate group identity. Similarly, access to a larger common market, reaping economies of scale in the provision of nation level public goods and availability of wider choice in the bundle of services to meet diverse preferences are some of the economic reasons for the smaller units to come together to form a federation. Each federating unit will try to bargain terms advantageous to it to join the federation while the federation will try to attract entry and control exit. In this situation, symmetry in intergovernmental relationships may not be possible.

"Asymmetric federalism" is understood to mean federalism based on unequal powers and relationships in political, administrative and fiscal arrangements spheres between the units constituting a federation. Asymmetry in the arrangements in a federation can be viewed in both vertical (between Center ${ }^{1}$ and states) and horizontal (among the states) senses. If federations are seen as 'indestructible union of indestructible states', and Center and states are seen to exist on the basis of equality; neither has the power to make inroads into the defined authority and functions of the other unilaterally. However, such 'purists' view of federalism is rarely, if at all, seen in practice. Even when the constitution guarantees near equal powers to the states, in the working on federal systems Center dominates in political, administrative as well as fiscal spheres. There is considerable volume of literature on Central domination in Indian federalism

\footnotetext{
${ }^{*}$ The authors are respectively, Director, National Institute of Public Finance and Policy, New Delhi, 110067. India and Professor of Economics, University of California, Santa Cruz. CA 95064. U.S.A. The first author is grateful to Amaresh Bagchi and Richard Bird for extremely useful discussions and detailed comments on the earlier draft of the paper. The usual disclaimers apply.

${ }^{1}$ The words "Centre", "Union", and "federal" are used interchangeably in this paper.
} 
in the assignment system in the Constitution and central intrusion into the States' domains in the working of the federation. ${ }^{2}$ Unlike the classical federations like the USA, Indian federation is not an 'indestructible union of indestructible states'. Only the Union is indestructible and the States are not. Article 3 of the Constitution vests the Parliament with powers to constitute new states by separating territories from the existing ones, alter their boundaries, and change their names. The only requirement for this is that the Bill for the purpose will have to be placed in the Parliament on the recommendation of the President and after it has been referred to the relevant State legislature for ascertaining their views (their approval is not necessary). The federation is not founded on the principle of equality between the Union and States either. The central government in India has the powers, and it actually does invade the legislative and executive domains of the states (Chanda, 1965, Rao and Sen, 1996, Rao and Singh, 2000). However, the nature and basis of relationship between Center and states is not the objective of this paper.

The focus of this paper is the usually understood aspect of asymmetry in fiscal arrangements in Indian federalism, namely, unequal arrangements and special treatment for some units within a federation. Such an arrangement is quite feasible in an arrangement evolved from bargaining and accommodation. It may also be desirable to have special powers and asymmetric arrangements to accommodate diverse group interests and identity and therefore, has an important role in 'coming together' federalism as well as 'holding together' federalism. But such accommodation can only be at the margin and cannot violate the basic fabric of equality and fair treatment of jurisdictions. This would also require transparency in the arrangements.

It is important to make a distinction between unequal arrangements or asymmetries that are (i) transparent and rule based evolved to facilitate the smooth functioning of the federation and (ii) those that are opaque and discretionary caused by the balance administrative and political power and expediency. The first may be built into the constitutional arrangement itself or may be evolved through conventions for the smooth functioning of the federation. This type of asymmetry is transparent and rule based and play is important role in building the nation. In contrast, the second type of asymmetry can simply the result of administrative and political power play in a federation. In India for example, the dynamics created by the end of single party

\footnotetext{
${ }^{2}$ For a survey of literature on centripetal bias in Indian constitution and in the functioning of Indian federalism see,
} 
rule in the center and states, emergence of coalition government at the center and regional domination of regional parties in the coalition and wielding power in the states can create asymmetries in the functioning of the federation on political considerations. This can have serious repercussions for the future of the federalism.

The paper examines the asymmetric features in Indian federalism and evaluates their contribution. Section 2 will explore the conceptual issues - the causes and consequences of asymmetric federalism. In section 3, we trace the evolution of Indian federalism and analyze the factors contributing to the asymmetric arrangements in political, administrative and fiscal relations. In section 4, we bring out asymmetric arrangements arising from constitutional arrangements or conventions evolved over the years. In this, we discuss the special arrangements in the Indian Constitution to accommodate special cases, such as Jammu and Kashmir, and the various northeastern hill states. Recent political developments and asymmetric treatment due to administrative and political exigencies are analyzed in Section 5. The main conclusions of the paper are summarized in the last section.

\section{Asymmetric Arrangements - Some Conceptual Issues}

According to Riker (1975), federalism is an outcome of rational bargain among various constituents. The bargain may be for political or economic gains. In the political bargain, the constituents give up political autonomy for security from external threat. The economic bargain is to enable a common market and to ensure optimal provision of public services by reaping economies of scale and catering to diverse preferences. However, while striking the bargain, the constituents try to preserve their valued identity and seek special status. Motivation for special status may be purely for expanding economic opportunities and securing freedom from exploitation by larger and more powerful members of the federation. The objective may be purely political - of enhancing freedom and representation to constituents or to maximize political power and influence. It may also be cultural or religious - of preserving group

Rao and Chelliah, (1997). 
identities. It may simply be a means of accommodating diverse group interests within a unified framework.

If federalism were an outcome of rational bargain among constituent units, differences in bargaining strength would be a source of asymmetry. If the issues at stake have general applicability to majority of units, then collective bargaining strength could result in greater decentralisation and all subnational units get greater autonomy. If on the contrary, the issues at stake have applicability or relevance to specific units and if they have the necessary strength to secure the special dispensation, then this could result in asymmetric arrangements in the federation. Such special arrangements may be de jure - enshrined in the constitution itself or established by tradition, or may be actually observed in practice (de facto) in the working of the federation. Such arrangements may be evolving. In many cases, special arrangements are accorded until the units are assimilated into the federation. In other cases, bargains may have to be struck by giving special status for holding the federation together. Yet other cases of asymmetry may arise purely by political alignments in a democratic polity. The way in which bargains are struck and special demands of various constituents are accommodated through asymmetric arrangements have a vital bearing on the stability of the federation.

Asymmetric arrangements need not necessarily be the outcome of constitutional arrangements. This can also result from the way in which administrative, political and fiscal systems are implemented in a federation. De facto asymmetry can also be desirable and can contribute to nation building if it is based on transparent principles. At the same time special arrangements instituted to meet short term political expediency or administrative discretion can cause secular degradation of intergovernmental institutions. Such arrangements can result in arbitrary conferring of special favors and in the long run can contribute to greater disharmony and instability in a federation.

In a centralized federation, the central government has considerable scope to discriminate among the units. The potential for discrimination will be particularly strong when the government at the center is weak and states wield significant control over the center even in a centralized federation. The issue is pertinent when we consider that regional parties in some states wield significant power over the coalition government at the center. 


\section{Evolution of Asymmetric Arrangements in Indian Federalism}

\subsection{Historical background:}

The distribution of power between the Center and States on the one hand and the treatment of different states on the other in the Indian constitution owe much to historical and political factors. Although the Cabinet Mission sent by the British Government in 1946 saw no virtue in partitioning undivided India into two different independent nations. It also recommended that the independent country should be governed by a federal constitution with the Central government dealing with only foreign affairs, defense and communications and remaining vested with two groups of provinces, one predominantly Hindu and the other predominantly Muslim. However, the insistence of the Muslim League to have a separate nation for the Muslims led to the formation of Pakistan comprising of Muslim majority regions of the Northwest part of the subcontinent and eastern part of Bengal. In the event, it was no longer necessary to create a weak federal government. Instead, the founding fathers of the constitution decided to have a federation with a strong central government to hold together the diverse economic, linguistic and cultural entities and to avoid fissiparous tendencies. Centralization was also found desirable to unify the country comprising of the regions directly ruled by the British and 216 princely states and territories ${ }^{3}$.

\subsection{Asymmetric structure at independence}

Thus, asymmetric arrangement in Indian federalism has a long history and goes back to the way in which the British unified the country under their rule and later the way in which the territories under the direct control of the British and various principalities were integrated in the Indian Union. While the territories ruled directly by the British were easily integrated into the Union, the treaties of accession signed by the individual rulers covered the integration of different principalities. The provinces ruled directly by the British had a modicum of autonomy and rudimentary form of parliamentary government as the British loosened the grip gradually from 1919. The Constitution that was adopted in 1951 itself classified the states into four 
categories. The provinces directly ruled by the British were classified as Part A states. Those princely States which had a relationship with the Government of India based on individual treaties signed were classified as Part B States. These included the States of Hyderabad, Mysore, Jammu and Kashmir and 5 newly joined unions of princely states. In the case of Jammu and Kashmir, the powers special powers were given in the terms of accession. The remaining princely states acceding to the union were grouped under Part $\mathrm{C}$ states. Finally, the territories ruled by other foreign powers gaining independence (French and Portuguese) and areas not covered in the above three categories were brought under the direct control of the union to form Part D states or Union Territories.

Thus, the Union of India in 1947 began with a major asymmetry between British India and the princely states and even among the latter, the terms of accession differed depending on the bargaining strength. In almost all cases, the princely states surrendered whatever notional sovereignty they had to the new country of India, in exchange for a guaranteed revenue stream: their "privy purses". The nature of this bargain was clear - security and money in exchange for giving up authority or residual control rights. This is close to the standard view of federation as a political bargain, with the difference that the successors of the British in India, the Indian National Congress, were in an extremely strong bargaining position, even relative to the coalition of the princes. This was illustrated in the case of the exceptions to voluntary accession, such as Hyderabad, where military force (the authority over which was also inherited from the British) ensured integration into the new Union.

\subsection{Assimilation of units after independence:}

While many of the former princely states, particularly the Part B states continued as administrative units after their integration into India, this continuation was not an essential part of the bargain. Furthermore, reorganization of state boundaries from 1953, freely permitted to the Center by Article 3 of the constitution, gradually eroded this status. The Constitution allowed sub-state structures for regions closely tied to some former princely states, but this had little practical import as the States became almost the sole significant subnational units of governance. Thus, in general, the princely states ceased to matter as geographic entities. In this

\footnotetext{
${ }^{3}$ For a detailed account of the history leading to Indian independence, see, Chanda (1965).
} 
respect, the outcome was completely different from the standard case of federation, where the constituents of the federation would normally retain their identities. Broadly, the asymmetric arrangement was recognition of the different set of institutions and administrative standards in the country, which, over the years was unified. The asymmetries present in 1947 with respect to almost all the princely states disappeared from Indian federalism.

\section{4, Special position of Kashmir:}

The sole exception, of course, was the state of Jammu and Kashmir ${ }^{4}$. While this state included several diverse populations and regions, the overwhelming majority of population in the Kashmir valley was Muslim, and the state bordered the new nation of Pakistan. The history of the conflict over Kashmir has been written on extensively, even though there is no consensus on the interpretation of events in 1947-48. Here, we merely note that the state acceded to the Indian Union under very special terms, which were subsequently incorporated in the famous Article 370 of the Constitution. This article provided the state with a unique position in the Indian Union, with its own constitution, a title interpreted as the equivalent of Prime Minister for its chief executive, and a special assignment of functional responsibilities. Specifically, the jurisdiction of the Center was restricted to foreign affairs, defense and communications, with the state's legislature having residuary powers. This was a striking contrast to the situation of other states, where the Center's assignment of responsibilities was much more extensive, and where the Center retained residuary powers.

\subsection{Integration of northeastern hill states}

The process of administrative reorganization of India focused on the creation of new boundaries based on the main principle of language. Typically, separate religious, caste, ethnic or tribal identities within these boundaries were not the basis for further divisions. One major exception to this has been the north-eastern part of India, where there is a distinct difference in ethnicity from the rest of India, and several strong divisions based not only on language, but also on culture and other traditions ("tribal", if one wishes to use that term). This part of India contains the states of Arunachal Pradesh, Assam, Manipur, Meghalaya, Mizoram, Nagaland, 
Sikkim and Tripura. Of these, only Assam has a population comparable to other typical Indian states. Most of these states were upgraded from the status of Union Territories, ${ }^{5}$, this reclassification giving them, at one level, a political status equivalent to that of larger states such as Bihar, Madhya Pradesh and Uttar Pradesh. Each state carries equal weight in mustering the 50 percent of states required to ratify an amendment to the Constitution.

Furthermore, there are various clauses in Article 371 which accord special powers to northeastern states. These provisions have been introduced through amendments, typically at the time of conversion of a union territory to a state, or in the case of Sikkim, after its accession to India. The safeguards provided to these states through these special provisions include respect for customary laws, religious and social practices, restrictions on the ownership and transfer of land, and restrictions on the migration non-residents to the State. State legislatures are typically given final control over changes in these provisions.

Thus, there are various provisions in the Indian Constitution to protect group rights, and to compensate for initial inequalities in the social system. Thus the Constitution, while recognizing the idea of fundamental human rights at the individual level, does not assume an idealized initial condition of equality, either in pure economic terms or otherwise. Thus there are allowances for separate laws to govern different religious groups, and there are provisions for various kinds of "affirmative action" for extremely disadvantaged groups. The first kind of provision simply respects diversity (though this can create issues of unequal treatment across subgroups, e.g., women in two different religious groups). The second attempts to correct for specific inequities, recognizing that legislative equal treatment from very unequal initial conditions would not achieve desired equity goals. Conceptually, at this level of ethical or normative judgement, there is no difference between these provisions and the ones for the indigenous residents of northeastern states, except that the latter happen to be geographically concentrated into reasonable administrative units. If that is the case, then the relationship to federalism is not essential.

\footnotetext{
${ }^{4}$ A good discussion on the asymmetric arrangements in Jammu and Kashmir and North-Eastern States can be found in Arora (1995)
} 


\section{Asymmetries in Practice in Indian Federalism:}

\subsection{Economic asymmetry}

The coming together of units with diverse history, resources, policies and institutions in a bargain to form a federation would certainly entail de facto asymmetry in terms of inter-state differences in geography, demography and economy. At present, there are 28 States in Indian federation in addition to 7 Union Territories ${ }^{6}$.

The wide differences in the economic characteristics between the states in Indian federation are highlighted in table 1. It is seen that in terms of area the biggest state, Rajasthan is 90 times bigger than the smallest state, Goa. Similarly, in terms of population size, Uttar Pradesh, the state with largest population is 308 times bigger than the smallest state, Sikkim. The density of population varies from 13 in Arunachal Pradesh to 901 in West Bengal. The state with the highest NSDP (Maharashtra) had 284 times that of the state with the lowest (Sikkim). There are significant variations in per capita incomes as well. In 2000-01, Goa, a small state in the western coast had the per capita Net State Domestic Product (NSDP) of Rs. 44613, which was almost 9 times that of Bihar with Rs. 4813.

For the sake of convenience of analysis, the States have been classified into special category states and non-special category states. The former States are those, that are given a special status in dispensing plan assistance by the Central government. The non-special category states in turn are classified into high-income, middle-income and low-income States based on their per capita $\mathrm{NSDP}^{7}$. It is seen from the table that 10 special category states with covering 14 per cent of geographical area of the country have just about 5 per cent of the population and they generate just about 4 per cent of the NSDP. The importance of non-economic factors in

\footnotetext{
${ }^{5}$ At independence, of course, this entire region except North eastern Frontier Area (NEFA) was administratively part of Assam province, and the union territories themselves were created by separation from Assam. Meghalaya was directly carved out of Assam state, while Sikkim was formerly an Indian protectorate. See, for example, Brass (1994) for a chronology.

${ }^{6}$ Union Territories are governed directly by the Central government. However, two Union Territories namely, Delhi and Pondicherry have their own elected governments and legislatures.
} 
determining the structure of federalism is underscored by the fact that most of the special category states are not economically viable. Even among non-special category states, there are states that are too large like Madhya Pradesh, Bihar and Uttar Pradesh even after carving out the three new states of Chattisgarh, Jharkhand and Uttaranchal respectively from the territories of these states in 2000 .

Within the non-special category states, there are wide variations in area, population and income levels. The high income states with about 18-19 per cent area and population generated 29 per cent of NSDP whereas the low income states with 43-45 per cent of geographic area and population accounted for only 28 per cent of income. There are wide variations in the sizes and income levels within each of the categories of states as well. On the whole, among the nonspecial category states, the most populous state (Uttar Pradesh) had 123 times the population of Goa, the least populous state and the income differences between the highest and lowest Income State was 36 times.

The above discussion brings out that economic viability has never been a consideration in demarcating the states in India. Nor has it been a factor in reorganization of the states despite the fact that the constitution empowers the central government to reorganize them. Thus, to begin with intergovernmental relationships are placed on an uneven economic keel. Naturally, uniform assignment system in an unevenly endowed federating system results in large differences in fiscal capacities. Varying sizes of states in terms of area and population, demographic compositions, different terrain and topography cause significant variations in the unit cost of providing public services varying expenditure needs and places a heavy burden of equalization on the intergovernmental transfer system.

\footnotetext{
${ }^{7}$ The states with per capita NSDP more than $15 \%$ of the average are classified as High income states and those with less than $10 \%$ of the average are classified as low income states.
} 


\begin{tabular}{|c|c|c|c|c|c|c|c|c|}
\hline \multicolumn{9}{|c|}{$\begin{array}{c}\text { Table } 1 \\
\text { Some Characteristics of States in Indian Federalism }\end{array}$} \\
\hline & $\begin{array}{c}\text { Area } \\
\text { (Sq. } \mathrm{Km})\end{array}$ & $\begin{array}{c}\text { Population } \\
\text { (in ‘000) }\end{array}$ & \begin{tabular}{|c} 
Density of \\
Pop
\end{tabular} & \begin{tabular}{|c|} 
NSDP \\
$1999-00$ \\
Rs. \\
Million
\end{tabular} & \begin{tabular}{|c|} 
Per capita \\
NSDP \\
$(1999-00)$
\end{tabular} & $\begin{array}{c}\text { Percentage } \\
\text { of Total } \\
\text { Area }\end{array}$ & $\begin{array}{c}\text { Percentage } \\
\text { of Total } \\
\text { population }\end{array}$ & $\begin{array}{l}\text { Percentage } \\
\text { of Total } \\
\text { NSDP }\end{array}$ \\
\hline High Income States & 601800 & 194065 & 322.5 & 4065770 & 22461 & 18.31 & 18.90 & 28.74 \\
\hline Gujarat & 196000 & 50597 & 258.1 & 896060 & 18685 & 5.96 & 4.93 & 6.33 \\
\hline Goa & 3800 & 1344 & 353.7 & 58620 & 44613 & 0.12 & 0.13 & 0.41 \\
\hline Haryana & 44000 & 21083 & 479.2 & 424880 & 21551 & 1.34 & 2.05 & 3.00 \\
\hline Maharashtra & 308000 & 96752 & 314.1 & 2131510 & 22604 & 9.37 & 9.42 & 15.07 \\
\hline Punjab & 50000 & 24289 & 485.8 & 554700 & 23254 & 1.52 & 2.37 & 3.92 \\
\hline Middle Income States & 725000 & 302633 & 417.4 & 4867930 & 17635 & 22.05 & 29.47 & 34.41 \\
\hline Andhra Pradesh & 275000 & 75728 & 275.4 & 1117530 & 14878 & 8.36 & 7.37 & 7.90 \\
\hline Karnataka & 192000 & 52734 & 274.7 & 862980 & 16654 & 5.84 & 5.13 & 6.10 \\
\hline Kerala & 39000 & 31839 & 816.4 & 569260 & 17709 & 1.19 & 3.10 & 4.02 \\
\hline Tamil Nadu & 130000 & 62111 & 477.8 & 1143090 & 18623 & 3.95 & 6.05 & 8.08 \\
\hline West Bengal & 89000 & 80221 & 901.4 & 1175070 & 14874 & 2.71 & 7.81 & 8.31 \\
\hline Low Income States & 1409300 & 458682 & 325.5 & 4022290 & 9013 & 42.87 & 44.66 & 28.44 \\
\hline Bihar & 94000 & 82879 & 881.7 & 383260 & 4813 & 2.86 & 8.07 & 2.71 \\
\hline Chattisgarh & 135100 & 20796 & 153.9 & 213310 & 10405 & 4.11 & 2.02 & 1.51 \\
\hline Jharkhand & 79700 & 26909 & 337.6 & 232270 & 9223 & 2.42 & 2.62 & 1.64 \\
\hline Madhya Pradesh & 308000 & 60385 & 196.1 & 677780 & 11626 & 9.37 & 5.88 & 4.79 \\
\hline Orissa & 156000 & 36707 & 235.3 & 311950 & 8733 & 4.75 & 3.57 & 2.21 \\
\hline Rajasthan & 342000 & 56473 & 165.1 & 710200 & 13046 & 10.40 & 5.50 & 5.02 \\
\hline Uttaranchal & 53500 & 8480 & 158.5 & na & $\mathrm{Na}$ & 1.60 & 0.83 & 0.00 \\
\hline Uttar Pradesh & 241000 & 166053 & 689.0 & 1493520 & 9323 & 7.33 & 16.17 & 10.56 \\
\hline General Category States & 2736100 & 955380 & 349.2 & 12955990 & 14605 & 81.89 & 93.02 & 91.59 \\
\hline Special Category States & 594000 & 63662 & 107.2 & \begin{tabular}{|l|}
63930 \\
\end{tabular} & 10695 & 17.78 & 6.20 & 4.52 \\
\hline Arunachal Pradesh & 84000 & 1091 & 13.0 & 14270 & 13352 & 2.56 & 0.11 & 0.10 \\
\hline Assam & 78000 & 26638 & 341.5 & 2533300 & 9720 & 2.37 & 2.59 & 1.79 \\
\hline Himachal Pradesh & 56000 & 6077 & 108.5 & 106570 & 17786 & 1.70 & 0.59 & 0.75 \\
\hline Jammu \& Kashmir & 222000 & 10070 & 45.4 & 121820 & 12373 & 6.75 & 0.98 & 0.86 \\
\hline Manipur & 22000 & 2389 & 108.6 & 28580 & 12721 & 0.67 & 0.23 & 0.20 \\
\hline Meghalaya & 23000 & 2306 & 100.3 & 29040 & 12063 & 0.70 & 0.22 & 0.21 \\
\hline Mizoram & 21000 & 891 & 42.4 & 12880 & 14909 & 0.64 & 0.09 & 0.09 \\
\hline Nagaland & 17000 & 1989 & 117.0 & 23300 & 12594 & 0.52 & 0.19 & 0.16 \\
\hline Sikkim & 7000 & 540 & 77.1 & 7580 & 14751 & 0.21 & 0.05 & 0.05 \\
\hline Tripura & 10500 & 3191 & 303.9 & 41930 & 13195 & 0.32 & 0.31 & 0.30 \\
\hline Uttaranchal & 53500 & 8480 & 158.5 & na & na & 1.60 & 0.83 & na \\
\hline All States & 3276600 & 1010562 & 308.4 & 13595290 & 14359 & 99.67 & 98.40 & 96.11 \\
\hline Uts & 10974 & 16453 & 1499.3 & 549870 & 31211 & 0.33 & 1.60 & 3.89 \\
\hline Total & 3287574 & 1027015 & 312.4 & 14145160 & 13778 & 100.00 & 100.00 & 100.00 \\
\hline
\end{tabular}

Notes: na - Not Available. All State NSDP figure does not include SDP from Uttaranchal.

NSDP figure of UTs excludes SDP from Dadra\& Nagar Haveli, Daman and Dieu and Lakshadweep. 
The implications of inter-state differences in economic conditions on fiscal variables of the states are shown in Table 2. The table brings out some important fiscal features of Indian federalism. First, variations in economic characteristics has resulted in significant differences in revenues collected in different states, partly due to differences in the capacity to raise revenues and partly due to differences in their collection efficiency. By and large, the ratio of revenues to SDP is positively related to the level of per capita. The low income states had lower revenue ratios than the middle income states, which in turn had lower ratios than the high income states. Second, the ratio of revenues to NSDP was much lower in special category states than general category states even when the latter had comparable levels of NSDP. The singular exception to this is the case of Sikkim, which had retained the power to levy income taxes while acceding to the country. Thus, unlike in other states Sikkim has the power to levy income tax and federal income tax can not extend to Sikkim. Third, the small size of jurisdictions in these states implies that they can not reap economies of scale in providing services. Besides, hilly and inhospitable terrain in these states means that the unit cost of providing public services will be higher than in other states. It is thus not surprising to see overwhelming dependence of special category states on central transfers. Thus, in 2001-02, non-special category states on average raised revenues to finance over 50 per cent of their current expenditure whereas in special category states it was just about 20 per cent. Thus, central transfers financed more than 80 per cent of the expenditures of special category states. In per capita terms, transfer to special category states is more than four times that of the average transfer received by general category states. 


\begin{tabular}{|c|c|c|c|c|c|c|c|}
\hline \multicolumn{8}{|c|}{$\begin{array}{c}\text { Table } 2 \\
\text { Revenues and Expenditures of the States - 2000-01 (RE) }\end{array}$} \\
\hline States & $\begin{array}{l}\text { Per capita } \\
\text { SDP } \\
\text { (Rupees) }\end{array}$ & $\begin{array}{c}\text { Poverty } \\
\text { ratio } \\
\text { (percent) } \\
1999-00\end{array}$ & $\begin{array}{l}\text { Per capita } \\
\text { own } \\
\text { revenue } \\
\text { (Rupees) }\end{array}$ & $\begin{array}{c}\text { Own } \\
\text { Revenue as } \\
\text { percentage } \\
\text { of SDP }\end{array}$ & $\begin{array}{l}\text { Per capita } \\
\text { Transfers }\end{array}$ & $\begin{array}{l}\text { Per capita } \\
\text { current } \\
\text { spending } \\
\text { (Rupees) }\end{array}$ & $\begin{array}{l}\text { Per cent of } \\
\text { own } \\
\text { revenue to } \\
\text { current } \\
\text { spending }\end{array}$ \\
\hline High Income States & 22461 & 17.83 & 2931.6 & 13.1 & 500 & 4386.6 & 66.8 \\
\hline Gujarat & 18685 & 14.07 & 2684.6 & 13.2 & 863 & 5167.6 & 52.0 \\
\hline Goa & 44613 & 4.4 & 14310.3 & 15.8 & 588 & 11904.8 & 120.2 \\
\hline Haryana & 21551 & 8.74 & 3209.7 & 12.1 & 502 & 4107.9 & 78.1 \\
\hline Maharashtra & 22604 & 25.02 & 2741.3 & 11.1 & 448 & 3852.6 & 71.2 \\
\hline Punjab & 23254 & 6.16 & 3333.2 & 10.2 & 494 & 4712.7 & 70.7 \\
\hline Middle Income States & 17635 & 20.3 & 1868.8 & 10.6 & 658 & 3400.4 & 55.0 \\
\hline Andhra Pradesh & 14878 & 15.77 & 1930.2 & 10.7 & 713 & 3320.2 & 58.1 \\
\hline Karnataka & 16654 & 20.44 & 2148.1 & 11.3 & 686 & 3580.9 & 60.0 \\
\hline Kerala & 17709 & 12.72 & 2295.8 & 10.2 & 690 & 3689.4 & 62.2 \\
\hline Tamil Nadu & 18623 & 21.12 & 2342.5 & 11.3 & 658 & 3594.3 & 65.2 \\
\hline West Bengal & 14874 & 27.02 & 1091.0 & 5.5 & 576 & 3092.7 & 35.3 \\
\hline Low Income States & 9182 & 34.28 & 858.5 & 9.3 & 673 & 2261.3 & 38.8 \\
\hline Bihar & 4813 & 42.6 & 338.2 & 8.9 & 724 & 1515.5 & 22.3 \\
\hline Chattisgarh & 10405 & NA & 1264.0 & 4.9 & NA & 2455.2 & 51.5 \\
\hline Jharkhand & 9223 & NA & 1128.0 & 9.0 & NA & 2229.4 & 50.6 \\
\hline Madhya Pradesh & 11626 & 37.43 & 1061.9 & 11.5 & 624 & 2695.5 & 39.4 \\
\hline Orissa & 8733 & 47.15 & 900.5 & 9.3 & 969 & 2785.3 & 32.3 \\
\hline Rajasthan & 13046 & 15.28 & 1297.2 & 10.4 & 693 & 2864.2 & 45.3 \\
\hline Uttaranchal & NA & NA & 1295.5 & NA & NA & 4912.7 & 26.4 \\
\hline Uttar Pradesh & 9323 & 31.15 & 791.2 & 8.1 & 598 & 2135.6 & 37.0 \\
\hline General Cat. States & 14605 & 25.97 & 1606.3 & 11.0 & 660 & 3060.9 & 52.5 \\
\hline Special cat. States & 10695 & & 1032.2 & 9.7 & 2896 & 5126.7 & 20.1 \\
\hline Arunachal Pradesh & 13352 & 33.47 & 1067.8 & 5.3 & 7985 & 9992.3 & 10.7 \\
\hline Assam & 9720 & 36.09 & 798.7 & 7.2 & 1216 & 3317.0 & 24.1 \\
\hline Himachal Pradesh & 17786 & 7.63 & 1660.5 & 7.8 & 3070 & 7420.6 & 22.4 \\
\hline Jammu \& Kashmir & 12373 & 3.48 & 1150.4 & 7.9 & 4602 & 6080.0 & 18.9 \\
\hline Manipur & 12721 & 28.54 & 406.0 & 3.1 & 3971 & 6032.3 & 6.7 \\
\hline Meghalaya & 12063 & 33.87 & 1066.8 & 6.3 & 3149 & 5878.4 & 18.1 \\
\hline Mizoram & 14909 & 19.47 & 679.0 & 3.8 & 9602 & 12845.6 & 5.3 \\
\hline Nagaland & 12594 & 32.67 & 506.8 & 3.7 & 6332 & 7291.0 & 7.0 \\
\hline Sikkim & 14751 & 36.55 & 5998.1 & 15.9 & 7945 & 12200.6 & 49.2 \\
\hline Tripura & 13195 & 34.44 & 729.6 & 4.8 & 3376 & 5838.9 & 12.5 \\
\hline Uttaranchal & na & & 1295.5 & & na & 4912.7 & 26.4 \\
\hline All States & 14359 & 26.1 & 1570.1 & 10.9 & 768 & 3191.1 & 49.2 \\
\hline
\end{tabular}

Source: 1. Finances of State Governments, 2001-02. Reserve Bank of Indi.a 2. CSO, Ministry of Planning, Government of India 


\subsection{Asymmetric design of the transfer system:}

Thus, the different position of special category states is reflected not only in structural asymmetries and fiscal arrangements, but very importantly in the methods and patterns of Central transfers to states. In some respects, the small size of these states is an advantage in this dimension. Transfers that are high in per capita terms for these states may not place a significant cost on the rest of the nation. In fact, even the entire group of these states has a population share that is just about 5 per cent and the rest of the members of the federation may not perceive this as a significant cost. Also, this small size encourages these states to combine politically for some purposes, in councils that allow them to coordinate policies, or to collectively negotiate with the Center. This is in contrast to the insignificance of zonal councils for other states.

To understand the asymmetry, it is necessary to refer briefly to the transfer system in Indian federalism. There are three sources of transfers from the Center to States. The first is the statutory transfers made on the recommendation of the Finance Commission appointed by the President of India every five years. The second channel of transfer is the assistance given for plan purposes by the Planning Commission. Finally, individual central ministries design transfers to enhance outlay on specified services in the states as desired by them. These central sector and centrally sponsored schemes are in the nature of close ended specific purpose transfers with or without matching requirements and are included in the plan schemes. There are over 200 such schemes initiated and administered by various central ministries. The allocation of resources in different states is also influences by regional policy followed by the central government including the direct central investments.

The framers of the constitution intended that transfers to states should be based on the recommendations of an impartial semi-judicial body appointed by the President every five years, the Finance Commission. So far eleven Finance Commissions have made recommendations. However, over the years, with the centralized development planning gaining focus, Planning Commission gained in importance as a dispenser of both grants and loans. Thus, the scope of the Finance Commissions has been confined to examining the non-plan requirements of the states and providing transfers to meet these requirements and Planning Commission has been assigned to deal with the plan requirements. Initially, volume of central assistance for state plans as well 
as its grant-loan composition was determined on the basis of the approved plan projects in different states. Since 1969 however, the allocation is determined on the basis of a formula determined by the National Development Council (NDC) ${ }^{8}$. However, over the years, with increased earmarking of central assistance for specific schemes, formula based component of central assistance for state plans has been reduced and in 2002-03, it is estimated at just about 46 per cent. In addition, as the central ministries exercised discretion in the transfers by increasing transfers under central sector and centrally sponsored schemes. Thus, as shown in table 3, the Finance commissions transfer about two thirds of the transfers and this has remained broadly constant over since the early 1970s. However, transfers given for both plan schemes and specific purpose transfers for central sector and centrally sponsored schemes have increased over time. What is more important, increasing proportion of assistance for state plan schemes has been kept outside the formula based distribution scheme and the proportion of normal assistance distributed according to the formula is just about 46 per cent of the total state loan assistance in 2002-03. Thus, on the whole discretionary element in the transfer system has shown a steady increase over the years. These are discussed in greater detail below.

\subsection{Finance Commission transfers:}

Finance Commission transfers comprise of tax devolution and grants. The Commission's methodology is to assess fiscal position of center and States, projecting revenues and non-plan expenditures of the states for the ensuing five years, augmenting the projected revenues by recommending share of central taxes to individual states based on the chosen general economic indicators and filling the remaining gap between non-plan expenditures and revenues with grants in aid. This is called the "gap-filling" approach.

\footnotetext{
${ }^{8} \mathrm{NDC}$ is an intergovernmental body presided over by the Prime Minister of the country and has the cabinet Ministers, Members of the Planning Commission and Chief Ministers of the states as members.
} 


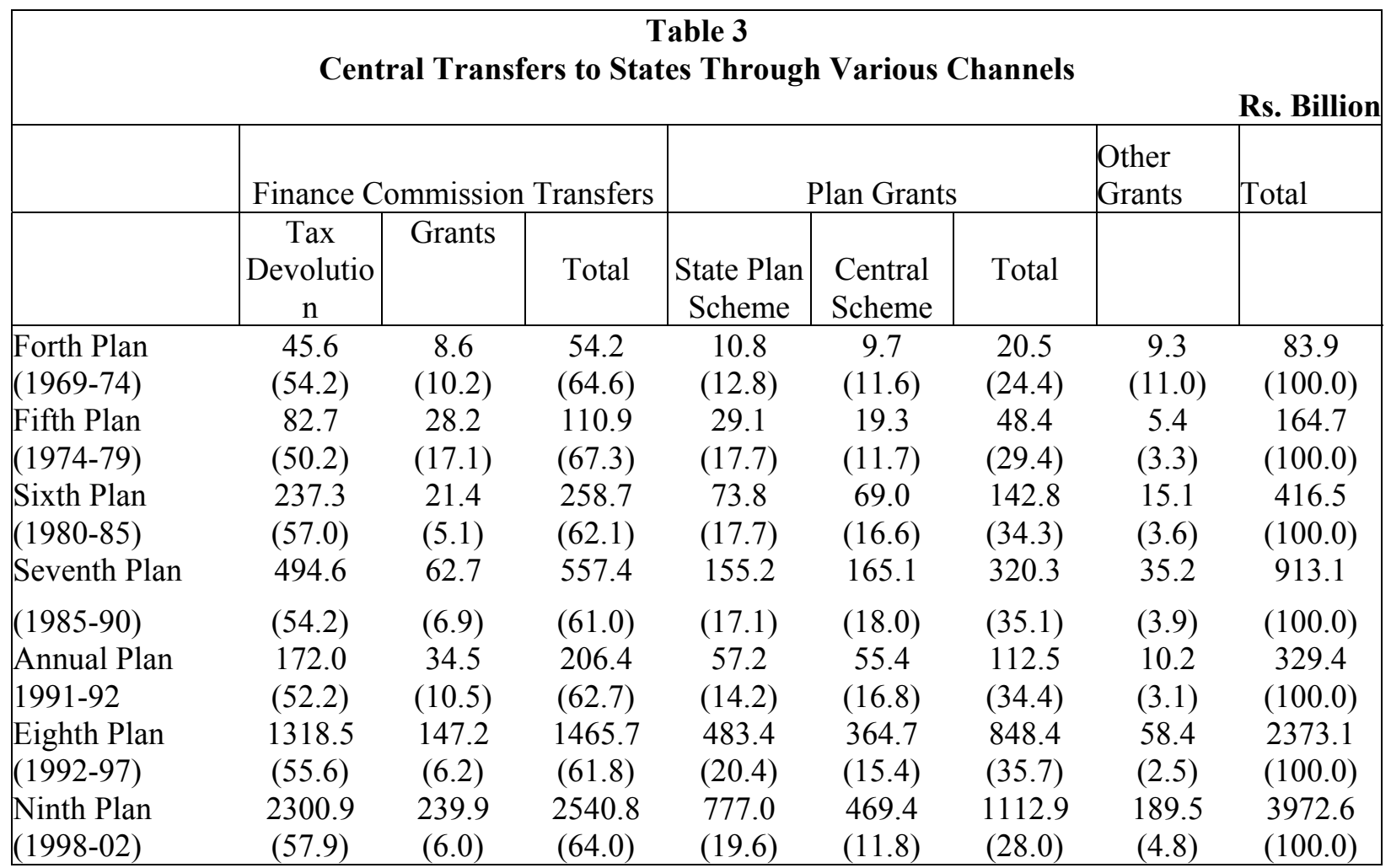

Note: Figures in parenthesis are percentages to total transfers.

Source: Indian Finance Statistics/Public Finance Statistics, Ministry of Finance, Government of India.

Discretionary elements enter into even the formula based transfers of the Finance Commission. The commissions determine the shares of the center and states in central taxes broadly on the basis of judgements pertaining to their relative requirements, but mostly on the basis of past shares. For the period 2000-05, the Eleventh Finance Commission recommended that 29.5 per cent of the net collections from central taxes should be transferred to the States. The relative shares are determined on the basis of general economic variables with weights assigned as shown in table 4. It is in the process of choosing the variables and assigning weights for them relative shares of the states may be influenced. This, however, need not 
necessarily be a source of unacceptable asymmetry as the formula used by the Commission is transparent. ${ }^{9}$

\begin{tabular}{|l|c|}
\hline \multicolumn{2}{|c|}{ Table 4 } \\
\multicolumn{2}{|c|}{ Criteria and relative weights for tax devolution } \\
\hline \multicolumn{1}{|c|}{ Criterion } & Weight (Per cent) \\
\hline 1. Population & 10 \\
\hline 2. Income (Distance Method)* & 62.5 \\
\hline 3. Area & 7.5 \\
\hline 4. Index of Infrastructure & 7.5 \\
\hline 5. Tax Effort** & 5.0 \\
\hline 6. Fiscal Discipline*** & 7.5 \\
\hline
\end{tabular}

Note: *The distance method is given by: $\left(\mathbf{Y}_{\mathbf{h}}-\mathbf{Y}_{\mathbf{i}}\right) \mathbf{P}_{\mathbf{i}} / \Sigma\left(\mathbf{Y}_{\mathbf{h}}-\mathbf{Y}_{\mathbf{i}}\right) \mathbf{P}_{\mathbf{i}}$ where, where, $\mathrm{Y}_{\mathrm{i}}$ and $\mathrm{Y}_{\mathrm{h}}$ represent per capita SDP of the $i^{\text {th }}$ and the highest income State respectively and $\mathrm{P}_{\mathrm{i}}$ is the population of the $i^{\text {th }}$ State .

** Tax Effort $(\eta)$ is estimated as $(\eta)=\left(T_{i} / Y_{i}\right) /\left(0.51 / Y_{i}\right)$ where, $T_{i}$ is the per capita tax revenue collected by the $i^{\text {th }}$ State and $Y_{i}$ is the per capita State domestic product of the $i^{\text {th }}$ State.

*** estimated as the improvement in the ratio of own revenue of a state to its revenue expenditures divided by a similar ratio for all States averaged for the period 1966-99 over 1991-1993.

It is because of this that the framers of the constitution intended the distribution of transfers should be mainly undertaken through the Finance Commission and Commission is supposed to be a statutory semi-judicial authority. However, the constitution of the commission, approach and methodology adopted by them and their recommendations have been a subject of controversy in recent times. Notable among the criticisms is the use of poverty ratio as a criterion for distributing the tax shares of the states by the ninth Finance Commission. It was argued that poverty alleviation is not an objective of general purpose transfers, and this should be taken care of by the direct anti poverty interventions initiated by rural development and urban development ministries. It is also argued that the transfer system should not be used to reward a state not making enough effort to alleviate poverty. More important criticism was the discretionary transfer made by the Ninth Finance Commission for the slum clearance in Bombay (Mumbai) and Calcutta (Kolkata) (Bagchi, 1988, Guhan, 1989). The Tenth Finance Commission

\footnotetext{
${ }^{9}$ There was, however, considerable controversy on the use of the variable 'poverty ratio' in tax devolution formula in the First report of the ninth Finance Commission. See, Bagchi (1988).
} 
was similarly criticized for making transfers for one state (Andhra Pradesh) as a compensation for the loss of revenue by following the prohibition policy ${ }^{10}$.

More serious criticism of the Finance Commissions is on the 'gap-filling' methodology. It is alleged that 'fiscal dentistry' practised by the commissions have led to enlargement of 'budgetary cavities'. The states can gain more by lowering their tax effort and indulging in profligate spending. In fact, serious deterioration in states' finances seen in recent years is in part attributed to the transfer system (Rao, 2002). This has resulted in the States resorting to frequent overdrafts. As the states had to seek greater ways and means assistance, each of the States was made to sign a Memorandum of Understanding (MOU) with the Center to initiate measures to bring about correctives. What is notable, however, is that the contents of the MOUs signed by individual states have not been placed in public domain. It is not known whether, the conditionalities are different for different states.

In spite of the MOUs, the fiscal position has shown a steady deterioration. Therefore, when the $11^{\text {th }}$ Finance Commission was about to submit its report, an additional term of reference was given to the Commission to '...draw monitorable fiscal reform program aimed at reduction of revenue deficit of the states and recommend the manner in which the grants to states to cover the assessed deficit in their non-plan revenue account may be linked to progress in implementing the program". Based on the recommendation of the Commission, the Centre has initiated the Medium Term Fiscal Reform Program (MTFRP) ${ }^{11}$. Accordingly, a small portion of the transfers has been earmarked for giving grants to the States on achieving five percentage point reduction in the percentage of revenue deficits to States revenue receipts including central transfers.

\footnotetext{
${ }^{10}$ Prohibition policy is the policy of prohibiting the consumption of sale of alcoholic products within the state. One state, Gujarat has consistently followed this policy right from independence and some states like Tamil Nadu and Aandhra Pradesh have followed this policy from time to time for electoral reasons.

${ }^{11}$ One of the members of the Commission, however, wrote a note of dissent stating that the recommended design is inappropriate.
} 
A number of shortcomings in the above scheme have been pointed out. The amount earmarked forgiving grants under MTFRP is constitutes less than 2 per cent of the transfers recommended by the Finance Commission. Along with other incentive based transfer schemes, this has contributed to further segmentation in the transfer system. More important criticism from the viewpoint of asymmetry is that in the case of special category states over 80 per cent of their revenues accrues from central transfers. Inability to reduce the deficit may be due to reduction in central transfers and this will be seen as the state's poor performance!

\subsection{Asymmetry in State Plan assistance:}

Asymmetric design in the transfer system in favor of special category states is seen very clearly in the distribution of plan assistance. Until 1969 plan assistance for state plan purposes was given according to the various plan schemes approved. To impart greater objectivity, the NDC approved the formula in 1969 and the assistance has been distributed to the states according to this formula modified by the NDC from time to time.

The asymmetry in the plan assistance is seen mainly between the special category states and non-special category states. The formula that is applied at present is summarized in table 4. First, 30 per cent of the central assistance for state plans is earmarked to the special category states even though their population share is only 5.4 per cent. Second, 90 per cent of plan assistance to special category states is given as grant and the remaining as loan whereas the proportion of grants in the plan assistance to other states is just 30 per cent (Table 4).

This arrangement cannot be entirely justified on equity grounds. Surely, equity provides some justification for this. They may reflect higher costs of providing the goods and services in remote mountainous areas, due to diseconomies of scale and scope arising from small sizes of these states, and their internal diversity. Thus, higher per capita spending than even high income states in these states seen in table 1 may partly reflect higher costs of provision. Higher transfers may also be needed to meet the special expenditure requirements, such as higher levels of security, that are not required in other states. Thus, these states may to some extent be acting as agents of the Center in the provision of the national public good of strategic stability and defense. A part of the reason for higher transfers to these states may be because, as they are 
located in international borders, the center has not allowed foreign investments to flow into these regions and therefore has the responsibility of strengthening the regions to have domestic investments.

\section{Table 5}

Formula for Distributing State Plan Assistance*

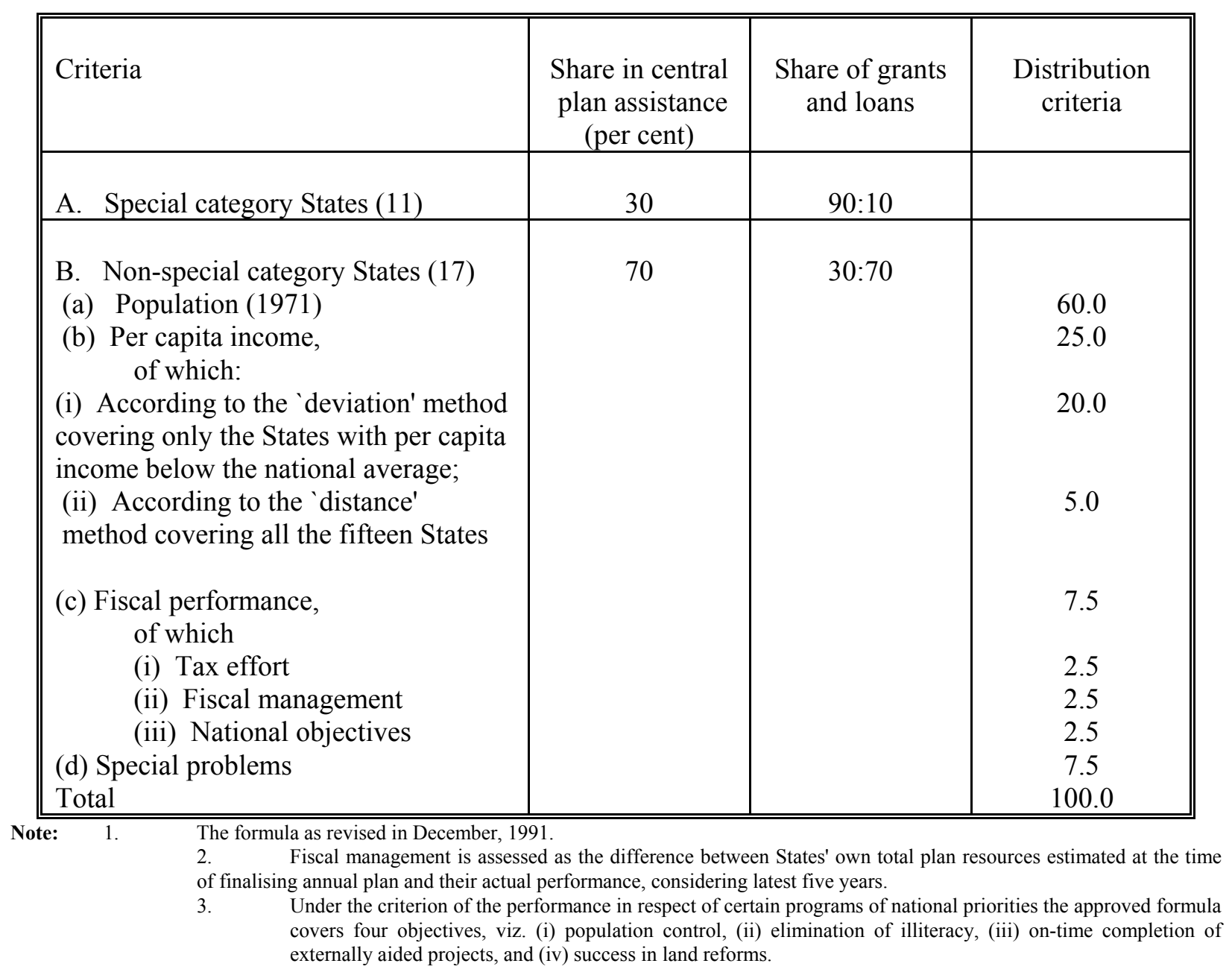

The more important reason for large transfers in these states has to be found in the political bargain that brought these areas firmly into the Indian Union, and keeps them there. This kind of reasoning is particularly clear for such formal, separate induction into the Union as Sikkim, and for the case of Kashmir, but it also applies to cases such as Nagaland, where a long insurgency after Indian independence was finally brought under some control through the 
granting of statehood with special provisions, and where an implicit political bargain may require continuing transfers beyond the average ${ }^{12}$.

A notable feature of the state plan assistance is the steady increase in its discretionary component. Although the transfers are supposed to be given according to the NDC formula, over the years, increasing proportion of the assistance has been earmarked for specific schemes and kept outside the formula based assistance. In 2002-03 for example, the normal plan assistance for state plan schemes disbursed on the basis of the NDC formula constituted only about 46 per cent of the total state plan assistance. The remaining portion included earmarked assistance such as schemes for hill, border and desert are4as, assistance to North-east and Sikkim, slum development, Accelerated Power Development, accelerated irrigation benefit program, Prime Minister's Gramodaya Yojana (village development plan) and Prime Minister's rural roads program.

An important component non-formula based assistance under state plan schemes is the pass through assistance from multilateral and bilateral donors to the state governments. In recent years, there has been a significant increase lending by multilateral and bilateral donors to the subnational governments and some discussion of this is in order. These loans are a part of state plan assistance and therefore, discussion on this is important. According to the seventh schedule to the constitution all matters pertaining to international affairs (10), having foreign jurisdiction (16), United Nations Organization (12) and foreign loans (37) fall within the jurisdiction of central government and states are not allowed to borrow or take aid directly from bilateral or multilateral donors. However, in recent years, the states have been allowed to negotiate directly with multilateral and bilateral donors though the loans are eventually routed through the Central government. This has enabled some states to seek substantial loans from multilateral donors whereas others have not been able to access the assistance. Naturally, the questions of propriety and partisanship in the selection of states have come up. The states ruled by regional parties with pivotal support to coalition government at the center may find it easier to access the facility

\footnotetext{
${ }^{12}$ One other possible reason also involves strategic motives. For strategic reasons, the central government may wish to restrict private investment, particularly, but not restricted to, foreign investment into these regions. Thus public spending may be a compensation for this restriction. To some extent, this is also a consequence of features of the political bargain that restrict non-residents of the state from certain kinds of ownership of property in the state, thus acting as a restriction on investment.
} 
than the states ruled by main opposition parties. In a situation in which most of the states are ruled my the main opposition party, the central government seems to have adopted a policy of going slow on this aspect of liberalization, though once started, the process is difficult to fold back.

The discussion in plan assistance is not complete without referring to the way in which the states' borrowing operations are conducted in Indian federalism. Article 293 of the constitution empowers the states to borrow internally. They can either borrow from the Center or from the market. It however, stipulates that they can borrow money from the market without referring to the Central government only if they are not indebted to the Center. The centralized planning has ensured that all states are indebted to the center and therefore, market borrowing by the states simply implies the allocation of market loans by the representatives of Union Ministry of Finance, the Planning Commission and the reserve bank of India. The stipulation of statutory liquidity ratio to the commercial banks ensures that the state governments' bonds are subscribed by the banking system.

The way in which both central loans and market borrowings are allocated to states is not made rule based and transparent and therefore, has attracted resentment by some states. Generally, after meeting the repayment liabilities, some additional resources are mobilized thorough these instruments for spending on plan schemes. Asymmetry can result from the volume of loans allocated to each state and the extent of interest rate repression. Until the early 1990 s, the rates of interest charged on market States' loans were substantially below the market rates of interest, but thereafter, interest rates have been better aligned to market rates. The whole process is not rule based and is opaque; there is significant scope for favouring some states over others in the allocation of market borrowing. This is particularly true in a government ruled by a coalition of parties and with some members of coalition wielding power in the states.

There can be tremendous scope for discrimination among the states arising from the practice of rescheduling and writing off of the loans on special considerations. In the past, a number of Finance Commissions were asked go into States' indebtedness and recommend rescheduling and writing off, and based on the recommendations, rescheduling was done. Referring the issue of states' indebtedness was only a convention that was established and not a 
constitutional necessity. In recent years, however, the central government has written off of States' loans in Punjab, Jammu and Kashmir and more recently proposes to write off loans of Nagaland without referring the issue to any body on a discretionary basis. The reasons advanced for the relief was that these states fought the nations battle on terrorism/insurgency and therefore have had to suffer loss of economic activity and revenues and therefore need to be compensated. They also had to create additional infrastructure to fight terrorism and a part of the loan spent on this should be written off. Whatever be the merits of these arguments, such practices have serious moral hazard problems and the arbitrary manner in which the central government decides to write off the loans of the states creates asymmetry and scope for discrimination, which may not be in the long-term interest of Indian federation.

\subsection{Central Sector and Centrally Sponsored Schemes:}

The most important scheme of differential treatment however is possible in the assistance given to states under a variety of central sector and centrally sponsored schemes. The former is funded entirely by the central government and the states are used merely as implementing agencies. The later, however, are closed ended specific purpose transfer programs intended to influence states' priorities in areas considered important by the central government. These do not have constitutional sanctity, given purely on discretionary basis ${ }^{13}$. Discretion enters in the choice of the schemes, their design and the way they are implemented.

There are over 200 Central sector and centrally sponsored schemes in vogue at present though, just 10 schemes account of over 75 per cent of the total assistance given for central schemes. The schemes are introduced by various central ministries and sometimes, on the basis of announcement made by the Prime Minister from time to time ${ }^{14}$. Once introduced, they are continued. While the central sector schemes are entirely funded by the Center, the centrally sponsored schemes are shared cost programs. But the schemes are designed by the central ministries, are mostly uniform across states. There is scope for discrimination between states in the selection of schemes and in its design. Often, new schemes can be introduced merely to favor a particular state or group of states. The transfers given under these schemes have received

\footnotetext{
${ }^{13} \mathrm{Mr}$. K. K. Venugopal, an eminent constitutional expert has opined that giving grants for these discretionary schemes is under Article 282 unconstitutional. See, NIPFP (1991).
} 
the strongest criticism, but that has not deterred the central government from initiating more schemes. Nor has there been any attempt to consolidate the schemes to allow greater say and flexibility to states in their design and implementation. The ways in which these are introduced and designed continue to be opaque.

\subsection{Other sources of asymmetry:}

In economies subject to centralized planning and particularly in those that had to traverse through acute scarcities, price and quantity controls on both inputs and outputs are common. Once introduced, these controls continue even when they have outlived their utilities, either because no one bothers to reassess them or they create strong vested interest for their continuance. In addition, there can be support prices on various commodities introduced and these tend to be much higher than border prices, introducing an element of implicit subsidy. All these price and quantity controls are sources of invisible transfers and can impact differently on different states. It is impossible to go into the plethora of such controls and invisible transfers in Indian federalism, but some important and obvious sources of inter-state discrimination may be pointed out.

Determination of procurement prices of foodgrains is an important source of invisible transfer. In an economy with high tariffs, when the support prices declared by the government are significantly higher than the prices that would have ruled in the market, and when the government owned Food Corporation of India guarantees to purchase the commodities at the declared price, the market prices will be necessarily higher than it would be otherwise. As the support prices are fixed mostly for agricultural commodities that are relatively price inelastic, this tends to have significant regional redistribution. This policy has a discriminatory impact on different states depending on the product (crop) chosen for fixing support prices and the extent to which support prices vary from the border prices (international price + transportation cost). Not surprisingly, determination of support prices on wheat, rice and other products is a matter of controversy in Indian federation. It is not uncommon to see some of the regional parties holding power in the states who are partners in the coalition government at the center influencing the determination of procurement prices.

\footnotetext{
${ }^{14}$ Independence day speech is one such occasion to make announcement on new schemes.
} 
Another recent example of price - quantity control system impacting on the resource distribution in asymmetric manner is the allocation of subsidized foodgrains to different states. The central government has the discretion to allocate foodgrains to states for distribution in fair price shops according to a formula determined by it, but it can exercise considerable discretion in distributing foodgrains for regions affected by draught and flood. It can send substantial relief to states ruled by the "friendly" parties and make token releases to those ruled by "unfriendly" ones. These examples can be multiplied.

Another important policy instrument that can discriminate between the states is through regional policies, particularly the policy regarding the location of central public sector enterprises and their head office and regional/zonal offices. In a planned economy, location decisions are not taken necessarily on the basis of economic considerations. In Indian case, during the first few plans, major investments in steel and Coal industries were made on the basis of backward and forward linkage considerations. However, in more recent years, the issue of locating central industrial units has been a subject of controversy. Similarly, the location of regional offices of railways has also been a subject of much discussion. Surely, this can be an important source of discrimination between the states.

\section{Political Elements in Asymmetric Practices}

A major source of asymmetric treatment of different states has to be found in the nature of Indian polity and the way in which political institutions have functioned over years. In the initial years of independence the issue did not come to the fore because, the Indian National Congress, which was in the forefront of independence movement had little opposition and had a virtual monopoly in forming the government at the center as well as states. Since at both central and state levels a single party ruled, and as the party itself was centralized, there was little scope for disharmony between the center and individual states and for discrimination between the states. However, four important developments in Indian federalism have impacted to create asymmetric treatment of States in Indian federation. These are discussed in the following.

The first important development is the increasing economic centralization of Indian 
federalism. To begin with, as mentioned earlier, the Constitution adopted in 1951 had a strong centripetal bias to be considered 'quasi-federal'. The centralization bias became stronger with the adoption of planned development strategy that required the concentration of economic powers and centralized allocation of resources. The concentration of economic power reached the pinnacle with the nationalization of Insurance and the important commercial banks in 1969. The concentration of fiscal and financial resources with the Center opened up vast scope for inter-state discrimination in the allocation of resources.

The second important development is the end of single party rule at the center and states. The continuation of the single party rule for relatively long period left two notable implications for intergovernmental relations. First, strong authority of the party, more particularly the Prime Minister had to be accepted and when there was a feeling of discrimination, it was ignored in the larger euphoria of planning for economic progress. Second, the concentration of power in the party and resolution of Center-State and inter-state issues through informal means through the party forum with the Prime Minister wielding paramount authority) meant that sufficient scope for development of formal and rule based intergovernmental systems did not exist.

The third important development was the emergence of parties with regional identity as ruling parties in some important states. In many states from time to time, electorate perceived that the regional interests and their distinct identity will be preserved better if they voted the regional parties to power. The emergence of two Drawidian parties alternating as ruling parties in Tamil Nadu, Telugu Desam reigning power in Andhra Pradesh, and other parties such as Haryana Vikas Party in Haryana, Biju Janata Dal with a distinct regional identity in Orissa are cases in point. This has shifted the perspective of parties on power at the State level towards strongly safeguarding regional interests even if that may beat the cost of rest of the country ${ }^{15}$.

Fourth, is the formation of coalition governments at the Center. As none of the national parties emerging victorious during the last two general elections, they had to forge alliances with other parties including regional parties to form governments. The regional parties could force their agenda and try to extract the maximum for the arrangements. This is particularly true when the parties had a pivotal standing in the coalition. 
Finally, in general, the time horizon of the politicians and parties has become more myopic in recent years. As electorate have become more cynical and their trust and faith in the politicians have shown a nosedive the probability of representatives getting reelected has declined sharply. In the last general election, only 38 per cent of the Members of Parliament got reelected whereas in the previous general election. Given that the probability of getting reelected is low, the elected representatives find it more worthwhile maximizing their personal gains when in office rather than working for the welfare of their electorate.

Thus, on the one hand, the central government continues to have enormous financial strength to dispense favors to state governments and on the other, has lost enormous power to prevent the strong states from bargaining and securing the allocation of resources in their favor. The states ruled by regional parties with significant strength in the Parliament have become pivotal and have been able to secure substantially higher resources relative to other states. This has been achieved by the fact that significant proportion of explicit and implicit transfers in Indian federation is discretionary. This dynamics of Indian federalism summarizes the recent developments in fiscal asymmetry in Indian federalism ${ }^{16}$.

\footnotetext{
${ }^{15}$ For the analysis of regional parties in India's federal system, see Manor (1995). And Rao and Singh (2001).

16 The above development has been a subject of consternation and concern. Referring to the tactics adopted by the Chief Minister of Andhra Pradesh, an editorial in a leading daily stated, "....Armed with several spiral folders listing myriad demands Mr. Naidu will characteristically show the folders around, and in all likelihood, have his way too. Like he easily managed to get 10 lakh tons of rice from the food for work program, a new international airport, a drought relief assistance and Rs. 1300.17 crores for countering extremism. .... Already, there are charges that a "weak" Center is being routinely "blackmailed" by Mr. Naidu. He has very cleverly used his political leverage to the maximum, and much to the discomfiture of his detractors, he has also got key Andhra politicians and bureaucrats into decision-making positions in Delhi” (Editorial in Asian Age, June 11, 2003)
} 


\section{Concluding Remarks}

This paper has attempted to bring out asymmetric arrangements in Indian federalism. Asymmetry in administrative, political and economic spheres in federal systems is unavoidable and in fact, may be necessary not only to 'come together' but also to 'hold together'. However, while transparent asymmetric arrangements that can be justified on grounds of overall gains to the federation contribute to the nation building, the discriminatory policies followed purely on short term political gains can be inimical to the long term interests and stability of federalism.

The rationale for asymmetry arises from the premise that inter alia, federalism is a rational bargain of various units. Thus, the terms of joining the federation depend on the bargaining strength. Further, even in a federation with no provision for exit, political alignments determine the bargaining strength of governments at different units in their interaction with center and this may result in discriminatory treatment of various units. The potential for discrimination is higher in more centralized federations and is inversely related to the political strength of the central governrnent vis-à-vis the various regional governments.

It is important to make a clear distinction between asymmetric arrangements which are rule based and transparent and those caused by political and administrative expediency. The asymmetric arrangements built in the constitutional framework itself and those that have been evolved to ensure smooth functioning of the federation belong to the first category. These are rule based and transparent and contribute to nation building. Over time, with changing situation, there may be changes in the arrangement depending on factors such as the extent to which various units assimilate themselves in the federation and their relative bargaining strength. In contrast, the asymmetric arrangements arising from political and administrative expediency are opaque and discretionary. They can lead to degradation of intergovernmental institutions and can be inimical to the stability of the federation in the long term.

The paper has analyzed both types of asymmetries in Indian federalism in respect of administrative, political and fiscal spheres, with greater emphasis on the last. It chronicles the growth of asymmetries over the years. It argues that the rule based and transparent asymmetry the special treatment to certain states accorded in the constitution and special treatment accorded 
to some of the states in evolving intergovernmental transfer system, have contributed to the health of the federation. In contrast, the discretionary treatment of states arising from changing configuration of political power structure, vagaries of coalition and regional party politics, weaken the institutions of intergovernmental finance and can be harmful to the stability of Indian federation in the long term.

\section{References:}

1. Arora, Balvir (1995), "Adapting Federalism to India: Multilevel and Asymmetric Innovations", in Balvir Arora and Douglas Verney (Ed), Multiple Identities in a Single State, New Delhi: Konarak Publishers.

2. Bagchi, Amaresh (1988), First Award of the Ninth Finance Commission - An Appraisal", Economic and Political Weekly, December 3.

3. Brass, Paul, R (1994), The Politics of India since Independence, 2nd Edition Cambridge, Cambridge University Press.

4. Chanda, A. K (1965), Federalism in India, London: George Allen and Unwin,

5. Guhan, S (1989), "The Norm and the Tilt: First Report of the Ninth Finance Commission", Economic and Political Weekly, January, 14.

6. Manor, James (1995), "Regional Parties in Federal Systems," in Multiple Identities in a Single State, ed. Balveer Arora and Douglas Verney, New Delhi: Konark Publishers.

7. Rao, M. Govinda and R. J. Chellaih (1997), Survey of Research in Indian Fiscal federalism, Indian Council of Social Science Research .

8. Rao, M. Govinda and Tapas Sen (1996), Fiscal Federalism in India: Theory and Practice, New Delhi: Macmillan India

9. Rao, M. Govinda and Nirvikar Singh (2000), "India's Federal Institutions and Economic Reform", Paper presented at the conference on "India's Public Institutions", Harvard University, (February)

10. Riker, William (1975), "Federalism," in Handbook of Political Science, Vol. 5, Fred I. Greenstein and Nelson W. Polsby, (eds.), Reading, MA: Addison-Wesley. 